\title{
Comments
}

\section{JURISDICTION OVER PARENT CORPORATIONS}

In the 1925 decision of Cannon Mfg. Co. v. Cudahy Packing Co., ${ }^{1}$ the United States Supreme Court firmly established the general rule that the presence of a subsidiary corporation in a state does not constitute "doing business" in that state by the parent corporation, and thus does not provide a basis for in personam jurisdiction over the parent. ${ }^{2}$ This respect for separate corporate entities can produce results inconsistent with the general treatment of foreign corporations under the "minimum contacts" approach to personal jurisdiction set forth in International Shoe Co. v. Washington. ${ }^{3}$ While the trend since International Shoe has been to base jurisdiction on minimal contact with the forum, the concept of separate entities, if followed rigidly, would dictate that extensive forum activity by a controlled subsidiary be ignored when determining jurisdiction over the parent. Significantly, many corporate families assign to wholly owned subsidiaries those business functions requiring widespread geographical activity, while leaving the parent company to act directly in only a few localities. ${ }^{4}$ This comment examines, in view of recent developments, the circumstances under which the subsidiary form can be expected to provide reliable jurisdictional insulation for the parent corporation.

The requirements of personal jurisdiction are twofold, one being the plaintiff's compliance with the particular jurisdiction statute and the other being the statute's compliance with due process. ${ }^{5} \mathrm{It}$ is important to recognize at the outset that the decision in Cannon was not based directly on due process limitations, but rather involved an interpretation of the meaning of "doing business" as used in a jurisdiction statute. ${ }^{6}$ Certainly the indication now seems to be that the presence

1267 U.S. 333 (1925), affirming 292 Fed. 169 (W.D.N.C. 1923).

2 The rule had been employed, but not as fully explained, in earlier Supreme Court decisions. People's Tobacco Co. v. American Tobacco Co., 246 U.S. 79 (1918); Peterson v. Chicago, R. I. \& Pac. Ry., 205 U.S. 364 (1907) ; Conley v. Mathieson Alkali Works, 190 U.S. 406 (1903). The Court has apparently invoked the rule only once since Cannon. Consolidated Textile Corp. v. Gregory, 289 U.S. 85 (1933).

3326 U.S. 310 (1945). See EnRenzwetg, Confutct of Laws 110-18 (1962); Note, Developments in the Law of State-Court Jutrisdiction, 73 HARv. L. REv. 909, 919-35 (1960); Note, Jurisdiction Over Foreign Corporation-An Analysis of Due Process, 104 U. PA. L. Rev. 381 (1955).

4 The decision to einploy a subsidiary is, of course, typically based upon a variety of business and tax considerations. See Murphy, Corporate Divisions v. Subsidiaries, Nov.-Dec .HARv. Bus. Rev. 83 (1956).

5 Note, Developments in the Law of State-Court Jurisdiction, 73 HARv. L. REv. 909, 998 (1960). See, e.g., Bhtzstein v. Ford Motor Co., 288 F.2d 738, 741 (5th Cir. 1961) ; Schmidt v. Esquire, Inc., 210 F.2d 908, 915 (7th Cir. 1954), cert. denied, 348 U.S. 819 (1954); Simonson v. Interuational Bank, 16 App. Div.2d 55, 225 N.Y.S.2d 392 (1962).

6267 U.S. at 336. Following removal of the action froun state to federal court, the district court could properly rule on any objections to the sufficiency of the service of process pursuant to North Carolina's "doing business" process statute for foreign corporations, N.C. GEN. Stat. \$\$ 55-143 (1960). Goldey v. Morning News, 156 U.S. 518, 525-26 (1895). While the Court stated that the claim for jurisdiction was not based on any state statute, it would seem that the Court was referring to the nonexistence of a statute dealing specifically with the presence of a subsidiary corporation. See Empire Steel Corp. v. Superior Court, 56 Cal. 2d 823, 830, 366 P.2d 502, 506, 17 Cal. Rptr. 150, 154 (1961). 
of a subsidiary would often be a sufficient "minimum contact" to satisfy due process in finding jurisdiction over the parent, ${ }^{7}$ although standing alone this factor would not satisfy any existing jurisdiction statute. ${ }^{8}$ Consequently it is the judicially interpreted scope of the statutes that determines when a parent is subject to suit in a state in which it has a subsidiary.

The jurisdiction problem under discussion presents two basic questions. One of these is the extent to which the contacts and activity of the parent company, apart from its corporate relationship with its subsidiaries, will subject it to jurisdiction. ${ }^{9}$ Where the conduct of the parent by itself is sufficient, under the current minimum contacts theory, to subject it to personal jurisdiction, the court will have no need to disregard the separate corporate entities. The second question concerns the occasions on which the existence of the parent-subsidiary relationship, in conjunction with other factors, may subject an absent parent to personal jurisdiction. Part I of this comment deals with obtaining jurisdiction over parent corporations apart from the existence of controlled subsidiaries; Part II considers the parent-subsidiary relationship as it affects jurisdiction over the parent.

\section{I}

\section{CONTACTS OF PARENT OTHER THAN THROUGH SUDSIDIARY}

With one minor exception, ${ }^{10}$ the state jurisdiction statutes do not deal specifically with the parent-subsidiary situation, so that the jurisdiction question typically arises withm the context of statutes which provide for jurisdiction over foreign corporations generally. Under these statutes conduct of the absent parent company may provide the basis for personal jurisdiction.

The majority of states continue to permit service of process on a foreign corporation only when it is "doing business" within the state. ${ }^{11}$ Under the usual interpretation of this term, originated before International Shoe, the corporation or its agents must be conducting some activity within the forum state. Thus if the

7 See Empire Steel Corp. v. Superior Court, 56 Cal. 2d 823, 829-30, 366 P.2d 502, 505-06, 17 Cal. Rptr. 150, 153-54 (1961) (dictum); EHRENZWEIG, CoNFIICT of LAWS 112-18 (1962); Note, Developments in the Law of State-Court Jurisdiction, 73 HARv. L. REv. 909, 932-33; Note, Jurisdiction Over Foreign Corporations-An Analysis of Due Process, 104 U. PA. L. REv. 381, 403-06 (1955).

8 In North Carolina, if the subsidiary is subject to suit in the state, the foreign parent corporation may be sued to impose liability arising from the subsidiary's obligations. N.C. GeN. STAT. $\S 55-145(\mathrm{~b})(1960)$. This statute thus requires more than the subsidiary's presence, and in effect combines both procedural and substantive disregard of the corporate entity. See text preceding note 54 infro.

8 This comment is limited to those developinents most directly related to common parentsubsidiary corporation problems. For inore general discussions of jurisdiction over foreign corporations, see authorities cited in note 3 supra; Foster, Personal Jurisdiction Based on Local Causes of Action, 1956 WIs. L. REv. 522; Reese \& Galston, Doing an Act or Causing Consequences as Bases of Judicial Jurisdiction, 44 Iowa L. REv, 249 (1959).

10 See note 8 supra.

11 Note, Developments in the Law of State-Court Jurisdiction, 73 HaRv. L. REv. 909, 1014-17 (1960). In addition to state court jurisdiction, a state's service of process statutes are also applicable in federal civil actions, FED. R. CIV. P. 4(d) (7), and the statutes creating federal causes of action generally fix jurisdiction similariy to state statutes. See, e.g., 38 Stat. 736 (1914), 15 U.S.C. $\$ 22$ (1958) (anti-trust). 
in-state acts are performed only by a subsidiary, recognition of separate entities would bar jurisdiction over the foreign parent. ${ }^{12}$

Cahfornia is a leading exception. Although its service of process statute still refers to "doing business,"13 the state supreme court has equated that term with the minimum contacts required by due process. ${ }^{14}$ In addition, California courts have consistently held that any corporation attaining a steady flow of its products into the state market will be subject to suit in the state on causes of action arising from that flow, regardless of the means used to obtain the trade. ${ }^{15}$ The emphasis in California is on the trade benefits acquired by the foreign corporation rather than the organizational methods employed to produce them. In a recent case a French car manufacturer was subjected to suit in a negligence action although all of its American business was handled by a wholly owned New York subsidiary, which in turn sold the automobiles to independent distributors in Cahifornia. ${ }^{10}$ The court, in upholding jurisdiction, observed that the manufacturer "inaugurates a flow of its products to the California market," " producing " 'a chain of sales leading from defendant Regie to California consumers." "17 With jurisdiction determined in this manner, separate corporate entities mean nothing in California when the cause of action against the absent parent arises from the local distribution of goods. The court in this situation need not look to the subsidiary's acts.

Many legislatures have been dissatisfied with their courts' narrow interpretation of "doing business," and at least nineteen states have enacted various statutes

12 Simonson v. Int'I Bank, 16 App. Div. 2d 55, 225 N.Y.S.2d 392 (1962) (no jurisdiction on showing only existence of parent-subsidiary relationship). New York has since broadened its jurisdiction statute. N.Y. Crv. Prac. LAw \& RuLEs $\$ 302$ (effective Sept. 1, 1963). Of course, if the corporations are not careful to use state boundaries to divide their areas of activity, the parent itself may have the contacts required to satisfy the "doing business" test. Certain-teed Prod. Corp. v. Wallinger, 89 F.2d 427 (4th Cir. 1937); Atlantic Greyhound Lines, Inc. v. Metz, 70 F.2d 166 (4th Cir. 1934); Bator v. Boosey \& Hawkes, Ltd., 80 F. Supp. 294 (S.D.N.X. 1948) (alternative ground).

13 CAL. Code Crv. Proc. $\$ 411(2)$. California did enact legislation to obtain jurisdiction over absent insurance companies, CAL. INs. CODE $\$ \S 1610-20$, which led to McGee v. Int'l Life Ins. Co., 355 U.S. 220 (1957), holding that an insurance company with no offices, agents, or solicitation in the state nevertheless had a substantial connection with California by insuring a resident.

14 Empire Steel Corp. v. Superior Court, 56 Cal. 2d 823, 366 P.2d 502, 17 Cal. Rptr. 150 (1961); Cosper v. Smith \& Wesson Arms Co., 53 Cal. 2d 77, 346 P.2d 409 (1959), cert. denied, 362 U.S. 927 (1960); Henry R. Jahn \& Son, Inc. v. Superior Court, 49 Cal. 2d 855, 323 P.2d 437 (1958). Cf. Blount v. Peerless Chem. (P.R.) Inc., 316 F.2d 695 (2d Cir. 1963); Jaftex Corp. v. Randolph Mills, Inc., 282 F.2d 508 (2d Cir. 1960). See Note, 10 Hastings L.J. 206 (1958).

16 Cosper v. Smith \& Wesson Arns Co., 53 Cal.2d 77, 346 P.2d 409 (1959), cert. denied, 362 U.S. 927 (1960) (non-exclusive sales representative); Regie Nationale Des Usines Renault v. Superior Court, 208 A.C.A. 762, 25 Cal. Rptr. 530 (1962) (independent distributors); Gordon Armstrong Co. v. Superior Court, 160 Cal. App. 2d 211, 325 P.2d 21 (1958) (mail solicitations and sporadic visits); Echipse Fuel Eng'r Co. v. Superior Court, 148 Cal. App. 2d 736, 307 P.2d 739 (1957) (whether service made representative, agent, or mdependent distributor irrelevant); Duraladd Prod. Corp. v. Superior Court, 134 Cal. App. 2d 226, 285 P.2d 699 (1955) (independent assembler and distributor); Fielding v. Superior Court, 111 Cal. App. 2d 490, 244 P.2d 968, cert. denied, 344 U.S. 897 (1952) (independent distributor). See Note, 10 Hastings L.J. 206 (1958).

16 Regie Nationale Des Usines Renault v. Superior Court, 208 A.C.A. 762, 25 Cal. Rptr. 530 (1962).

Ir Id. at $763,25 \mathrm{Cal}$. Rptr. at 531 , quoting from the trial court decision. 
aimed at exercising a greater part, if not all, of the state's judicial jurisdiction consistent with due process. These so-called "single-act" statutes in general provide for jurisdiction based on the defendant's isolated acts that produce the cause of action, rather than the traditional concept of doing business. It is as yet uncertain, however, whether most of these single-act statutes will remove the need to disregard separate entities in order to reach the absent parent company. Fourteen of the statutes authorize service on an absent defendant only upon committing a tort or entering into a contract "in" the forum state. ${ }^{18}$ Only three of the fourteen statutes having the "in" requirement have been before the courts where the defendant caused harmful consequences in the state without physically having entered it. This situation frequently arises in contract, libel, and manufacturer's negligence cases. The Minnesota and Alabama statutes have been held inapplicaable in the absence of any physical presence, ${ }^{19}$ while the similarly worded Illinois act lias been held applicable. ${ }^{20}$ If the defendant must enter the state, the courts will still be faced with the entity problem when all local activities are conducted by a subsidiary. Such statutes should prove useful, however, in giving the court jurisdiction when, despite the allocation of functions to the subsidiary, the parent finds it necessary to perform an occasional act within the state, and that act gives rise to the plaintiff's cause of action. ${ }^{21}$

Connecticut, Florida, Montana, North Carolina, and Wisconsin have enacted statutes specifically extending jurisdiction to defendants who cause certain harm-

18 AIA. Code tit. 7, § 199(1) (1960); ARK. Stat. ANN. § 27-340 (1962); IDAHO Code § 5-514 (Supp. 1961); Irr. Stat. Ann. § 17 (1956); LA. Rev. Stat. Anv. § 13:3471 (Supp. 1962) (corporations only) ; Me. Rev. Stat. ANN. ch. 112, §21 (Supp. 1961); MD. ANN. Code art. 23, § 92(d) (1957) (corporations only; art. 75, \& 78 covers noncorporate defendants); MnnN. Stat. Ann. \& 303.13(3) (Supp. 1962) (corporations only); Miss. Code AnN. \$ 1437 (1956); N.M. Stat. ANn. 21-3-16 (Supp. 1961); N.Y. CTv. Prac. LAw \& RULEs § 302 (effective Sept, 1, 1963); VT. STAT. ANN. tit. 12, §855 (1958) (corporations only); WASH. Rev. CODE ANN. \$ 4.28.185 (1962); W. VA. Code ANN. \$3083 (Supp. 1961) (corporations only). Other states have employed the single-act approach in special situations, such as workmen's compensation cases, N.J. STAT. ANN. \& 34.15-55.1 (1959), or in dealing with absent insurance companies, Cax. Ins. Code $\$ \$ 1610-20$. See statutes collected in Restatement (SEcoND), Conflicts of LAw, Reporter's Notes $\$ 84$ (Tent. Draft No. 3, 1956).

10 New York Times Co. v. Connor, 291 F.2d 492 (5th Cir. 1961) (Alabama statute held inapplicable to bibel publislied outside the state); Mueller v. Steelcase, Inc., 172 F. Supp. 416 (D. Minn. 1959) (manufacturer's neghigence). The Alabama Supreme Court, however, recently Ireld on the facts of Connor, supra, that a libel is committed "in" the state where the reporter came into the state in the process of gathering data for the libelous article, which was printed outside the state and distributed in it. New York Times Co. v. Sullivan, 273 Ala. 656, 144 So. 2d 25 (1962), cert. granted, 83 Sup. Ct. 510 (1963). Thus an "in" requirement may not provide a distinct cut-off line. See Note, Personal Jurisdiction in Minnesota over Absent Defendants, 42 MnNN. L. Rev. 909, 917-18 (1958). See generally Stimson, Omnibus Statutes Designed to Secure Jurisdiction Over Out-of-State Defendants, 48 A.B.A.J. 725 (1962).

20 Gray v. American Radiator \& Standard Sanitary Corp., 22 IIl. 2d 432, 176 N.E.2d 761 (1961) (manufacturer's negligence action). Before Gray interpreted the Illinois statute, the federal courts lad supposed that it did not apply. Kaye-Martin v. Brooks, 267 F.2d 394 (7th Cir. 1959) (contract action); Insull v. New York World-Telegram Corp., 172 F. Supp. 615 (N.D. MI. 1959) (libel action) ; Hellriegel v. Sears Roebuck \& Co., 157 F. Supp. 718 (N.D. 11. 1957) (manufacturer's negligence action). See Cleary and Seder, Extended Jurisdictional Bases for the Illinois Courts, 50 Nw. U. L. REv. 599 (1955).

21 See New York Times v. Sullivan, 273 Ala. 656, 144 So. 2d 25 (1962), cert. granted, 83 Sup. Ct. 510 (1963); discussed in note 19 supra. 
ful consequences in the state without having entered it. ${ }^{22}$ If obtaining a regular flow of products or causing consequences in a state is accepted under these statutes as a justifiable basis for asserting jurisdiction, it becomes unnecessary to ascribe the subsidiary's physical presence to the parent corporation. The parent's acts elsewhere will suffice, and the result would be the same as that reached by the California courts. Nevertheless, in controversial decisions rejecting flow of trade as a permissible minimum contact, the North Carolina statute, as applied in certain fact situations, has been held to violate due process. ${ }^{23}$ None of the cases, however, have involved parent and subsidiary corporations. ${ }^{24}$

The net effect of the statutory enactments and interpretations in the states discussed above is to reduce the number of occasions on which the court must disregard corporate entities to establish jurisdiction. Nevertheless, the limited number of states that have changed their jurisdiction statutes, and the narrow applicability of those statutes that have been modernized, leave many situations in which the courts must still look to the parent's use of a subsidiary if jurisdiction over the parent is to be found.

\section{II}

\section{EFFECT OF PARENT-SUBSIDIARY RELATIONSHIP}

Under the same statutes discussed in Part $I$, the parent-subsidiary relationship may provide the necessary connection for gaiming jurisdiction over the foreign

22 Conn. Gen. Stat. ANN. \$ 33-411 (1960) (corporations only); Fla. Stat. \$§ 47.16-161 (1961) ; Mont. Rev. Codes ANN. § 93-2702-2 B (Supp. 1961); N.C. Gen. Stat. § 55-145 (1960) (corporations only); WIs. Stat. ANN. \$262.05(4) (Supp. 1963) (see Revision Notes following statute). The statutory language in each instance will determine the range of application. For example, Montana would assert jurisdiction where the action arises from "the commission of any act which results in accrual within this state of a tort action." By contrast, Wisconsin requires that, in addition to the act outside the state leading to personal or property injury in the state, "(a.) Solicitation or service activities were carried on within this state by or on behalf of the defendant; or (b.) Products, materials or things processed, serviced or manufactured by the defendant were used or consumed within this state in the ordinary course of trade." (Empliasis added.) See Reese \& Galston, Doing an Act or Causing Consequences as Bases of Judicial Jurisdiction, 44 IOwA L. REv. 249 (1959).

23 Erlanger Mills v. Cohoes Fibre Mills, 239 F.2d 502 (4th Cir. 1956) (contact limited to single, unsohited contract); Walker v. P. Ballantine \& Sons, 149 F. Supp. 379 (M.D.N.C. 1957) (regular sales througl independent distributor); Moss v. City of Winston-Salem, 254 N.C. 480, 119 S.E.2d-445 (1961) (manufacturer had no sales or contacts in state); Putnam v. Triangle Publications, Inc., 245 N.C. 432, 96 S.E.2d 445 (1957) (publisler had regular sales through independent distributor). Except for Moss, supra, the decisions seem inconsistent with McGee v. International Life Ins. Co., 355 U.S. 220 (1957), discussed in note 13 stupra, and Restatement (SECOND), Conflicts of Law \$§ 84, 91a (Tent. Draft No. 3, 1956). See Cardozo, The Reach of the Legislature and the Grasp of Jurisdiction, 43 CORNELX L.Q. 210 (1957); Latty, Some Miscellaneous Novelties in the New Corporation Statutes, 23 LAW \& CoNTEMP. ProB. 363, 395-97 (1958); Sobeloff, Jurisdiction of State Courts Over Non-Residents in Our Federal System, 43 CorNent L.Q. 196 (1957) (Judge Sobeloff wrote the Erlanger opinion); Stimson, Omnibus Statutes Designed to Secure Jurisdiction Over Out-of-State Defendants, 48 A.B.A.J. 725 (1962); Note, 7 DUke L.J. 135 (1958).

24 In fact, the Wisconsin and Connecticut statutes have yet to be interpreted in any context. The Florida statute, note 22 supra, has been held to apply only when personal property is distributed through a local wholesaler, distributor, or jobber. Newark Ladder \& Bracket Co. v. Eadie, 125 So. 2d 915 (Fla. 1961). Even then it is interpreted as applying only if the absent defendant has some control over the local distributor or the property. Fawcett Publications, Inc. v. Rand, 144 So. 2d 512 (Fla. 1962). These narrow constructions should not interfere with an action involving a distributor that is a subsidiary of the absent manufacturer or publisher. 
parent corporation where the local activities of the parent itself would not be sufficient. For example, the courts which reject the trade-benefits approach ${ }^{25}$ would most likely uphold jurisdiction over a corporation using a subsidiary in the forum state, on the basis that the activities of the subsidiary provide the minimum contact. ${ }^{26}$ When the liberal single-act statutes ${ }^{27}$ are applied in the context of a manufacturing parent able to closely control a subsidiary's distributing activities within the state, there slould be little question of the fairness of holding the parent subject to suit in that state. ${ }^{28}$ The salutary effect of these statutes is to force the producer of goods, who benefits from mass distribution, to provide buyers with an adequate local remedy.

The North Carolina statute furtler contains a section specifically making a foreign parent corporation subject to suit in an action to impose liability for the obligations of a subsidiary that is subject to suit in the state. ${ }^{29}$ To come under the section, the obligation must be that of the subsidiary, and the plaintiff must allege some basis for holding the parent substantively liable for that obligation. ${ }^{30}$

The largest impact of the parent-subsidiary relationship, however, is in its effect on the application of the "doing business" jurisdiction statutes. As will become apparent, a variety of situations exist in which jurisdiction can be obtamed over a foreign corporation because it has a subsidiary within the forum state. All involve, to some extent, disregarding the separate corporate entities.

Domination and control by the parent is normal in the parent-subsidiary relationslip. Therefore it generally has been recognized that a finding of control or instrumentality should be used to disregard the corporate entity only when "to recognize their separate entities would aid in the consummation a wrong." The Cannon decision, rejecting the control language, stated that the presence of a wholly owned subsidiary in a state does not constitute "doing business" by the parent so long as formal intercorporate barriers are observed and the subsidiary is not serving formally as the parent's agent. ${ }^{32} \mathrm{Mr}$. Justice Brandeis, writing for a unanimous Court, recognized as legitimate the use of controlled subsidiaries to

25 See note 23 supra.

26 In Putnam v. Triangle Publications, Inc., 245 N.C. 432, 96 S.E.2d 445 (1957), the court was apparently unwilling to accept a regular flow of the defendant's magazines into the state as a sufficient minimum contact where the sales went through independent contractor wholesalers; the court made special note that the publisher had no financial interest in the wholesalers. 245 N.C. at 435,96 S.E.2d at 448 . Thus an inference can be drawn that jurisdiction would have been found if the wholesalers were somehow affiliated with the defendant. See Curtis Publishing Co. v. Cassel, 302 F.2d 132 (10th Cir. 1962), discussed in text at note 45 infra.

27 See text following note 21 supra.

28 See WIS. STAT. ANN. \$262.05(4) (Supp. 1963), discussed in note 22 supra; Cleary \& Seder, Extended Jurisdictional Bases for the Illinois Courts, 50 Nw. U. L. REv. 599 (1955); Note, Personal Jurisdiction in Minnesota over Absent Defendants, 42 MnN. L. REv. 909 (1958).

20 N.C. GEN, STaT. \$ 55-145(b) (1960), discussed in note 8 supra. See Latty, Some Miscellaneous Novelties in the New Corporation Statutes, 23 LAw \& ConTEarP. ProB. 363, 396 (1958).

30 The statute does not appear to require that the cause of action arise in the state. See N.C. Gen. Stat. \$ 55-145(b) (1960).

31 Ballantine, Separate Entity of Parent and Subsidiary Corporations, 14 CALIR. L. REv. 12, 19-20 (1925). See LatTy, Subsmiarmes and Afrimiated Corporations 156-92 (1936) for a thorougl, case-by-case demonstration that the instrumentality, alter ego, and control language is valueless as a criterion for determining when the separate entities will be observed or disregarded to impose substantive liability.

32 Cannon Mfg. Co. v. Cudahy Packing Co., 267 U.S. 333 (1925). 
avoid service of process, and ruled that the Court's decisions disregarding corporate entities to enforce "substantive rights" were inapplicable when jurisdiction alone was at issue. ${ }^{33}$

Although Cannon has come to stand for a "rule" applicable under all circumstances, ${ }^{34}$ the facts of the case do not strongly support such a general application. The suit involved the plaintiff's contract with the foreign parent for out-of-state delivery of goods to the parent. ${ }^{35}$ The cause of action was thus unrelated to the local subsidiary's activities or to the forum state.

Courts desirous of avoiding the Cannon rule have established three ways to circumvent it: (1) finding a failure to maintain formal intercorporate separation; (2) finding an agency relationship between parent and subsidiary; and (3) factually distinguishing Cannon on the relationship of the cause of action to the subsidiary and the forum.

\section{A. Insufficient Intercorporate Separation}

A breakdown in the formal intercorporate barriers will seldom be encountered in a well-run corporate family, but occasionally a court can find that one of the corporations is no more than a bookkeeping entry, ${ }^{36}$ or that the parent has no function other than owning the subsidiary's stock. ${ }^{37}$ A potentially more pliable loophole, utilized by a few courts, has been to find a breakdown of the separation when the corporations represent themselves as a single unit in their advertising. ${ }^{38}$ The leading example is State ex rel. Grinnell Co. v. MacPherson, ${ }^{30}$ a recent New Mexico decision. In that case the parent steel manufacturer had a sales subsidiary active in the state, but the particular defective girder which injured the plaintiff was sold to a local builder by another subsidiary which was not otherwise active in the state. If the entities were observed, therefore, the local subsidiary would not be liable, and neither the manufacturer nor the seller would be subject to suit

$33 I d$. at 337-38. It is not clear from the language whether the Court would always treat jurisdiction and substantive liability separately, but there appears no positive indication that the Court would not establish jurisdiction if the case involved substantive liability of the parent for the subsidiary's obligations. North Carolina has enacted a jurisdiction statute that makes the parent's substantive liability a criterion for jurisdiction over an absent parent. See note 8 supra.

The trial court in Cannon Mfg. Co. v. Cudahy Packing Co., 299 Fed. 169 (W.D. N.C. 1923), expressed the substance-jurisdiction distinction when it stated,

... while the courts generally have held that they will look through corporate fictions to prevent such fraud or to enforce just linbility, yet I know of no case where it has been found that a separate legal corporate entity can have process served upon it and such process take the place of process on some other separate legal corporate entity. Id. at 176.

See LATTY, op. cit. supra note 31, at 60-64; Ballantine, supra note 31, at 14-15. infra.

34 E.g., Harris v. Deere \& Co., 223 F.2d 161 (4th Cir. 1955), discussed in text at note 42

35267 U.S. at 333-35. None of the other Supreme Court decisions on point, cited in note 2 supra, clearly involved actions closely related to the forum state; the facts are not clear in Conley v. Mathieson Alkali Works, 190 U.S. 406 (1903).

36 Mas v. Orange-Crush Co., 99 F.2d 675 (4th Cir. 1938).

37 United States v. Buffalo Weaving \& Belting Co., 155 F. Supp. 454 (S.D.N.Y. 1956).

38 S.O.S. Co. v. Bolta Co., 117 F. Supp. 59 (N.D. Ill. 1953) ; Gray v. Eastman Kodak Co., 53 F.2d 864 (E.D.Pa. 1930) ; State ex rel. Grinnell Co. v. MacPherson, 62 N.M. 308, 309 P.2d 981, cert. denied, 355 U.S. 825 (1957).

39 Supra note 38. 
under the state's "doing business" statute. Although the parent and its two selling subsidiaries were meticulous in keeping their books separate, the court noted that they had similar names and referred to themselves as a unit in catalogs and other advertising. ${ }^{40}$ On the theory that these representations breached the entity barriers, the court held the absent defendants subject to suit. ${ }^{41}$ Given the prestige of size in the business world, it seems likely that plaintiffs may often be able to find similar corporate names and representations of unity in advertising. Yet it remains to be seen whether other courts will accept these factors, standing alone, as a ground for disregarding the entities in order to find jurisdiction.

\section{B. Subsidiary as Agent of the Parent}

Finding an agency relationship between the parent and subsidiary is difficult if the search is limited to the forms the corporations use, as Cannon contended. It abdicates to the corporation's lawyers the power to determine when the parent will be subject to suit. A recent example of the Cannon rule is found in Harris $v$. Deere $\& \mathrm{Co}_{0}{ }^{42}$ where the plaintiff could not sue an allegedly negligent tractor manufacturer, in the state of injury, because the manufacturer's extensive sales in the state were handled by a wholly owned subsidiary. The Court of Appeals for the Fourth Circuit reluctantly followed Cannon because the two corporations lhad scrupulously maintained separate books and had a straight sales agreement rather than a formal agency. The court concluded that so long as only the subsidiary had contact with the state, the parent could avoid being subject to suit. 43

With increasing frequency, lowever, the courts are looking beyond form to consider realistically the parent's control of the subsidiary, and are finding agency on this basis.4 This may be done with a pretense of looking only to form, as in Curtis Publishing Co. v. Cassel, ${ }^{45}$ which involved a libel action brought in the plaintiff's home state against a foreign publisher whose distributing subsidiary was doing business in the state. In its scrutiny of the contract between the parent and subsidiary, the court encountered a common provision in magazine distribution contracts giving the distributor credits for unsold copies. This clause indicated agency, the court reasoned, because "the risk of success or failure in publication is taken by the parent." 48 While the court purported to fulfill the formalistic requirements of Cannon, it is apparent that the contract clause, without the factor of parental control, would not ordinarily lead to a finding of agency for jurisdiction purposes. ${ }^{47}$

4062 N.M. at 312-18, 309 P.2d at 984-88.

41 Ibid. Since the plaintiff doubtless did not know of the representations at the time of injury, the doctrine of estoppel does not appear to explain the result.

42223 F.2d 161 (4th Cir. 1955).

$43 \mathrm{Id}$. at $162-63$.

44 E.g., Massey-Harris-Ferguson, Ltd. v. Boyd, 242 F.2d 800 (6th Cir.), cert. denied, 355 U.S. 806 (1957) ; Alfred Hofmann \& Co. v. Karl Mayer Erste, 159 F. Supp. 77 (D.N.J. 1958) ; In re Siemans \& Halske A.G., Berlin, 155 F. Supp. 897 (S.D.N.Y. 1957); Waldron v. British Petroleum Co., 149 F. Supp. 830 (S.D.N.Y. 1957); United States v. Watchnakers of Switzerland Information Center, 134 F. Supp. 710 (S.D.N.Y. 1955); Williams v. Campbell Soup Co., 80 F. Supp. 865 (W.D. Mo. 1948); Streifer v. Cabol Enterprises, Ltd., 35 Misc. 2d 1049, 231 N.Y.S.2d 750 (1962); Goodman v. Pan Am. World Airways, 1 Misc. 2d 959, 148 N.Y.S.2d 353, aff'd, 2 App. Div.2d 707, 153 N.Y.S.2d 600 (1956).

45302 F.2d 132 (10th Cir. 1962).

46 Id. at 138 .

47 The same clause was involved in Putnam v. Triangle Publications, Inc., 245 N.C. 432, 96 S.E.2d 445 (1957), discussed in note 26 supra, where the court denied jurisdiction without considering that the financially independent wholesalers might be serving as agents. 
In most instances in which courts find an agency relationship the realities of parental domination are considered and the forms are not mentioned.8 These courts recognize that the parent's ability to control the subsidiary's policies makes illusory any apparent independence in contracts between the corporations, for whenever parent and subsidiary do business together, it will be the ultimate good of the parent and its shareholders that prescribes the subsidiary's course of action. ${ }^{49}$ Consequently, having a subsidiary operating in a state affords the parent the same benefits as would exist if its own noncorporate employees or agents were present. Courts have readily found the local subsidiary to be the parent's agent in antitrust cases, where the substantive allegation itself is that the parent, subsidiary, and others have illegally engaged in concerted trade programs. ${ }^{50}$ Also, where the subsidiary is primarily a distributor for the parent, the courts are increasingly inclined to find that the controlled subsidiary is in fact an agent of the parent, although the control itself is not the illegal act complained of. ${ }^{61}$ The agency inquiry focuses attention on the parent-subsidiary relationship, rather than the relationslip among the plaintiff, the corporations, and the forum; on one occasion it has been used where the action related to neither the subsidiary nor the forum. ${ }^{62}$ At any rate, by opening inquiry to the ever-present control factor, the agency requirement has changed from a restriction on asserting jurisdiction to a means of reaching out for the absent parent.

\section{Parent's Relation to Subsidiary and Forum}

When for any reason the court does not find an agency relationship or a failure to maintain formal separation, jurisdiction over the parent still may be obtained,

48 See note 44 supra.

49 For example, the control function of the parent Standard Oil Company (New Jersey) has been described:

An affliate may importune from the heat of competitive struggle or the environment of a foreign country, but (as with the Roman Empire) Jersey can never accede to a major request from a family member without considering what the reverberations through the provinces will mean to the larger interest-that of the Jersey company itself.

Guzzardi, How Rathbone Runs Jersey Standard, Fortune, Jan. 1963, p. 85.

50 E.g., Massey-Harris-Ferguson, Ltd. v. Boyd, 242 F.2d 800 (6th Cir.), cert. denied, 355 U.S. 806 (1957); In re Siemans \& Halske A.G., Berlin, 155 F. Supp. 897 (S.D.N.Y. 1957); Waldron v. British Petroleum Co., 149 F. Supp. 830 (S.D.N.Y. 1957) ; United States v. Watchmakers of Switzerland Information Center, 134 F. Supp. 710 (S.D.N.Y.1955). All appeared to involve parent corporations that would have avoided suit in the United States entirely if the agency finding had not been made. While the device of the agency finding is most commonly employed, the courts might just as readily directly disregard the entities to make the parent and subsidiary a single entity. This was done in Intermountain Ford Tractor Co. v. MasseyFerguson Ltd., 210 F. Supp. 930 (D. Utah 1962), where Cannon was distinguished on the amount of detailed control.

51 E.g., Alfred Hofmann \& Co. v. Karl Mayer Erste, 159 F. Supp. 77 (D.N.J. 1958); Williams v. Campbell Soup Co., 80 F. Supp. 865 (W.D. Mo. 1948); Streifer v. Cabol Enterprises Ltd., 35 Misc. 2d 1049, 231 N.Y.S.2d 750 (1962).

52 Goodinan v. Pan Am. World Airways, 1 Misc. 2d 959, 148 N.Y.S.2d 353, aff'd, 2 App. Div. 2d 707, 153 N.Y.S.2d 600 (1956). This case involved an action against an airplane manufacturer for alleged negligence resulting in a Brazilian crash; the local New York sales subsidiary did not appear to have any connection with the action. Althougl no other state had a special interest in the cause of action, the plaintiff could bave sued all the defendants in adjoining Connecticut. Contra, Anderson v. British Overseas Airways Corp., 144 F. Supp. 543 (S.D.N.Y. 1956); State St. Trust Co. v. British Overseas Airways Corp,, 144 F. Supp. 241 (S.D.N.Y. 1956). In both cases the denial of jurisdiction meant that the plaintiff had to travel to Great Britain to sue the manufacturer. 
'based on the parent's close connections with the subsidiary and with the forum. These two factors, both missing in Cannon, may serve as the court's justification for disregarding the entities to establish jurisdiction. Thus, where the plaintiff seeks to impose substantive liability on the parent for obligations of the nowinsolvent subsidiary, several courts have held the parent subject to suit on that basis in the state in which the subsidiary was operating. ${ }^{53}$ Here the jurisdiction question depends on whether the complaint states a cause of action calling for disregard of the separate entities in order to impose substantive liability. However, once jurisdiction is fixed the basis used for disregarding the entities need not restrict the scope of the suit. In one case the plaintiff established jurisdiction in conjunction with the parent's liability for rendering uncollectible the plaintiff's claim against the subsidiary, yet the action also adjudicated a claim against the parent for its separate acts of patent infringement. ${ }^{54}$

California's interpretation of "doing business" as being equivalent to due process minimum contacts has made it unnecessary for the court to disregard the entities to obtain jurisdiction over a parent. In Empire Steel Corp. v. Superior Court ${ }^{55}$ the foreign parent corporation caused the sales subsidiary to continue operating without adequate capital to the detriment of the plaintiff who was a California creditor of the bankrupt subsidiary. Although the court expressed at length its view that the entities could properly be disregarded to establish jurisdiction as well as substantive hability in such a case, ${ }^{56}$ it finally chose to establish jurisdiction on the parent's own minimum contacts in manipulating the subsidiary's finances ${ }^{57}$ Here the wrongful use of the subsidiary, which could lead to a substantive disregard of the separate entities, becomes the minimum contact for holding the parent subject to suit. Either way, the court did not permit the parent to direct the subsidiary in such a way as to deprive its creditors of an adequate local remedy.

Even approacles unrelated to obtaining jurisdiction over the absent parent niay be employed for the purpose of providing redress in a local forum. In one such case, Bathory v. Proctor \& Gamble Distrib. Co., ${ }^{58}$ the court rescued a plaintiff, who was unable to obtain jurisdiction over a parent, by imputing the parent manufacturer's neghigence to the local distributing subsidiary.$^{59}$ Concluding that the usual limited measure of duty owed by a distributor was inapplicable in the parent-subsidiary situation, the court observed,

We do not think that one department of a manufacturing and selling enterprise which puts a dangerous product into the channels of trade can escape liability by saying that it did not know what another department of such an integrated operation was doing. ${ }^{60}$

53 Henderson v. Rounds \& Porter Lumber Co., 99 F. Supp. 376 (W.D. Ark. 1951); Acme Card System Co. v. Remington Rand Business Serv., 21 F. Supp. 742 (D. Md. 1938); Empire Steel Corp. v. Superior Court, 56 Cal.2d 823, 366 P.2d 502, 17 Cal. Rptr. 150 (1961) (dictum). 1938).

54 Acme Card System Co. v. Remington Rand Business Serv., 21 F. Supp. 742 (D.Md.

5556 Cal. 2d 823, 366 P.2d 502, 17 Cal. Rptr. 150 (1961), 9 U.C.L.A. L. REv. 249 (1962).

56 Id. at 829-31, 366 P.2d at 505-07, 17 Cal. Rptr. at 153-55.

57 Id. at 832-33, 835, 366 P.2d at 507-09, 17 Cal. Rptr. at 155-57.

58306 F.2d 22 (6th Cir. 1962).

59 If the entities are observed, plaintiff will often be left without a local remedy where a manufacturing parent has a distributing subsidiary, since the distributor of goods manufactured by another ordinarily has no duty to inspect or test the product to discover a dangerous condition. Restatement, Torts $\S 402$ (Supp. 1948). See Prosser, Torts 491-93 (2d ed. 1955); Prosser, The Assault Upon the Citadel (Strict Liability to the Consumer), 69 YaLE L.J. 1099, 1114-24, 1141-42 (1960); Wilson, Products Liability, 43 CarIF. L. Rev. 614, 635,(1955).

60306 F.2d at $28-29$. 
Underlying the opinion, but never mentioned in it, was the fact that the trial court had set aside service on the manufacturing parent, and had dismissed the warranty count against the distributor because notice of the product's defects had been given only to the manufacturer. ${ }^{61}$ Another court, in subjecting the selling distributor to suit on allegations of negligence by a cosubsidiary manufacturer of dynamite caps, asserted that "it would be an interference with the public convenience, a wrong and a fraud" to make the plaintiff travel to another state to sue the manufacturer. ${ }^{62}$

Shifting liabilities to the locally available subsidiary is a questionable cure for the jurisdiction problem. Confusion is created as to the tort standards of care. Moreover, shiftmg liability would seem improper if the parent did not own all of the subsidiary's stock, since otherwise private shareholders of the subsidiary might be made to pay the parent's obligations. As already discussed, other courts have taken the direct route of holding the parent subject to suit. This could have been done in Bathory, for example, on virtually every ground discussed thus far. The companies had similar names and advertised without distinguishing between the entities, the distribution contract shifted all risks of business loss to the parent, the subsidiary's primary business function was distributing the parent's goods, and the action arose in the forum state through the use of the subsidiary's services. ${ }^{03}$

\section{CONCLUSION}

It is clear from the recent cases and stautory developments that use of separate corporations does not assure the parent total jurisdictional insulation in states where the subsidiary acts. In the effort to make absent defendants subject to suit on the basis of fewer contacts with the forum state, legislatures and courts are not always willing to permit formal corporate separations to be decisive. The courts are not, however, subjecting a parent to suit on every transitory cause of action wherever a subsidiary operates. ${ }^{64}$ The courts have shown no inclination to use the devices for disregarding the entities where the action does not relate to the forum state ${ }^{65}$ or where an action against the local subsidiary would be adequate. ${ }^{60}$ Thus Cannon is probably still good law on its facts. However, some courts persist in rigidly applying the Cannon rule even where the cause of action relates directly

61 Petition for En Banc Rehearing, p. 21.

62 Green v. Equitable Powder Mfg. Co., 95 F. Supp. 127, 132 (W.D. Ark. 1951). At least two earlier cases held the local corporation for a foreign affiliate's wrongs where the only apparent justification was the travel inconvenience to the plaintiff. Costan v. Manila Elec. Co., 24 F.2d 383 (2d Cir. 1928), involved a suit by a California resident against a New York holding company for injuries incurred on a Philippine subsidiary's Manila streetcar. Specht v. Missouri Pac. R.R., 154 Minn. 314, 191 N.W. 905 (1923), was a suit by a Minnesota plaintiff for injuries incurred at a Nebraska railyard operated by the Minnesota defendant's Nebraska subsidiary. See LatTy, Substorartes and Affitated Corporations 208 (1936).

63 Bathory v. Proctor \& Gamble Distrib. Co., 306 F.2d 22, 28-30 (6th Cir. 1962).

64 Perkins v. Benguet Consol. Mining Co., 342 U.S. 437 (1952). See REstatearent (Second), Confutcts of Law § 92, cominent $c$ (Tent. Draft No. 3, 1956).

65 E.g., Blount v. Peerless Chem. (P.R.) Inc., 316 F.2d 695 (2d Cir. 1963); Echevarry v. Kellogg Switchboard \& Supply Co., 175 F.2d 900 (2d Cir. 1949) ; Steiner v. Dauphin Corp., 208 F. Supp. $104^{\circ}$ (E.D. Pa. 1962).

${ }^{68}$ Gravely Motor Plow \& Cultivator Co. v. H.V. Carter Co., 193 F.2d 158 (9th Cir. 1951); Hendricks v. Alcoa Steamship Co, 203 F. Supp. 33 (E.D.Pa. 1962); Fergus Motors, Inc. v. Standard-Triumph Motor Co., 130 F. Supp. 780 (S.D.N.Y. 1955); Vaughan Motors, Inc. v. Societe Anonyme des Automobiles Peugeot, 30 Misc.2d 1047, 220 N.Y.S.2d 292 (1961). 
to the forum, refusing to distinguish Cannon on its facts. ${ }^{67}$ Other courts have avoided Cannon by the simple expediency of fitting the cases before them into one or another of the exceptions.

The biggest questions as to the scope of Cannon's vitality arise because the courts often fail to articulate their ratio decidendi in parent-subsidiary jurisdiction cases, ${ }^{68}$ and because many courts have not decided such a case in recent years. Those courts that have decided such cases only rarely permit an absent parent who causes harm in the state to hide behind the entity shield. Recent precedents afford ample support for any court desirous of holding a parent subject to suit. In jurisdiction cases, judicial tools appear readily available to prevent separate entities from aiding in "the consummation of a wrong." 69

Daniel I. Reith

67 Manville Boiler Co. v. Columbia Boiler Co. of Pottstown, 269 F.2d 600 (4th Cir. 1959) (patent infringement); Berkman v. Ann Lewis Shops, Inc., 246 F.2d 44 (2d Cir. 195\%) (action against parent as guarantor of subsidiary's debt); Harris v. Deere \& Co., 223 F.2d 161 (4th Cir. 1955), discussed in text at note 42 supra.

${ }^{88}$ After studying the cases shifting substantive liability, Professor Latty concluded:

So long as the technique resorted to, when recovery is demed, is to assert that a corporation is something separate and distinct from the stockholder, and where recovery is allowed, to assert that the corporation is not separate and distinct when it is so controlled and dominated as to be a more instrumentality, we may continue to expect confusion. Armed with these two verbally conflicting major premises, any court can reach either result in the typical parent-subsidiary situation and still leave us no nearer enlightment than before.

LatTy, Subsidiaries and Afritited Corporations 220 (1936). The statement is equally applicable to the parent-subsidiary jurisdiction cases.

69 Ballantine, Separate Entity of Parent and Subsidiary Corporations, 14 CaLrF. L. Rev. $12,19-20$ (1925). 